\title{
The Impact of Fraudulent Practices on Infrastructural Development in Nigeria
}

\author{
ADEKUNLE Olufemi $^{1} \quad$ OLUSA Adekemi $^{2}$ \\ 1.Petroleum Equalization Fund, Lagos \\ 2.Department of Urban and Regional Planning, Federal University of Technology, Akure
}

\begin{abstract}
Infrastructure is one of the most substantial services that is necessary to put in place in order to boost the economy of the nation. The economy of Nigeria can be alleviated and speed up by the presence of good infrastructure. Fraudulent practice is a ruinous and composite practice openly acknowledged in Nigeria, even it continues to exists in all activities of the nation. The fraudulent acts has turn to be beneficial for both government and private parastatal while being problematic to the citizens of the nation without resort to solution out of this peril. This study is based on the impact of fraudulent practices on infrastructural development in Nigeria with impression of making meaningful suggestions for economy development. Fraud has affected a lot of infrastructural development in Nigeria such as power blackout, inadequate piped water, undependable healthcare services, unstable educational systems, bad roads that leads to traffic congestion, fuel scarcity, inadequate telecommunication services, poor irrigation and industrial water. The study proposed that, to efficaciously undertake these challenges and take rewards then all public office holders should always be monitored with a great sense of accountability through adequate checks and balances and government should encourage a culture of transparency through the publication of all expenditures and also the presence of whistle-blowing mechanisms will be an advantage if implemented in order to reduce fraud in all infrastructural sectors. The problems of fraudulent in all infrastructural sectors if it is not well tackled, could surely menace the chances of good economy development in Nigeria.
\end{abstract}

Keywords: Accountability, Development, Economy, Fraudulent Practices, Infrastructure.

DOI: $10.7176 / \mathrm{JESD} / 12-6-08$

Publication date:March $31^{\text {st }} 2021$

\section{INTRODUCTION}

The rising incidence of fraudulent practices in Nigeria and the public service in particular and the poor state of infrastructure in the country has turned to issues of public concern. Many agencies have been established through modifying acts and reforms undertaken to combat fraudulent practice and development of infrastructure in Nigeria. Infrastructure are necessary items that should be put in a place in order to enhance development. Economic development of Nigeria can be eased and induced by the presence of infrastructure. If necessary facilities and services are not in place, development in that nation will be very unmanageable and commodities can only be secured at a very high price.

The Federal Government's National Economic Empowerment and Development Strategy in Nigeria (NEEDS) stressed fighting fraudulent acts (NPC, 2004). The NEEDS also has as one of its policy trust to "develop and maintain adequate/appropriate infrastructure." (NPC, 2004). In its bid to escalate the combat against fraudulent acts in infrastructural development, the Federal Government of Nigeria ordained laws and installed many institutions which include; the Independent Corrupt Practices and other Related Offences Commission (ICPC) Act 2000, the Economic and Financial Crimes Commission (EFCC) created by the EFFC Act 2004 and the Bureau of Public Procurement established through the Public Procurement Act, 2007. Other establishments are the Nigerian Extractive Industry Transparency Initiative (NEITI) established through NEITI Act 2007 and the Freedom of Information Act of 2011, concerned with the crumbling infrastructure facilities in Nigeria also, the Federal Government of Nigeria approved a National Integrated Infrastructure Master plan on $2^{\text {nd }}$ November 2012 (Usman, 2013).

The state of infrastructure in Nigeria is not less distressful. Akinwale (2010) observed that attempt made to upgrade the state of infrastructure by sequential administrations in Nigeria failed due to negligence, and this leaves the country with various cases of inadequate infrastructure such as power blackout and inadequate piped water, undependable healthcare services, unstable educational systems, bad roads that leads to traffic congestion, fuel scarcity, inadequate telecommunication services, poor irrigation and industrial water, all these bear witness to the inadequate existing infrastructure.

The state of infrastructure in Nigeria has now become a matter of great concern also the consequence of the sector on the economic growth and development as well as the well-being of the people (Uhunmwuangho \& Christopher, 2012). Alabi \& Ocholi (2010) stated that infrastructures are grossly inadequate and inequitably spread where available and in a state of decay which could be attributed to inability to provide infrastructure to meet the needs of the teaming population as a result of influx of population into the cities due to migration and high birth rate. The World Economic Forum in 2012, ranked Nigeria 127 out of 133 countries and 135 out of 139 covered in 
2009/2010 and 2010/2011 respectively in terms of infrastructural development. The country's ranking for 2011/2012 and 2012/2013 were 135 out of 142 and 130 out of 144 countries respectively (Usman, 2013). Nigeria is the 116th most competitive nation in the world out of 140 countries ranked in the 2018 edition of the Global Competitiveness Report published by the World Economic Forum.

Fraudulent practice/Fraud is one of the greatest obstacle precluding Nigeria from achieving its tremendous potential. It has drained billions of dollars from the country economy, obstructs the social development of the nation and weakens the infrastructural development of the nation. It has become so blatant and widespread that it appears as if it has been legalized in Nigeria (Gire, 1999). Fraud has been the primary reason behind the country's difficulties in developing fast ecomic growth (ICPC, 2006). This study assessed the impact of fraudulent practices on infrastructural development in Nigeria.

\section{The Concept of Fraud}

Edelherz (1977) defined fraud as an illegal act or series of illegal acts committed by nonphysical means and by concealment or guide to obtain money or property, to avoid the payment or loss of money or property or to obtain business or personal advantage. In Taiwan, the Statement on Audit Standards (SAS) No 43 defined fraud as the inappropriate or illegal behaviour which management, administrative units or over one of the employee used fraudulent schemes intentionally to obtain benefits. ACEF categorized fraud mainly into assets misappropriation, fraudulent statement and corruption. The fraudulent statement was defined as misstating or omitting the important facts or accounting data deliberately to deceive users of financial statements so that they changed the judgment or decision.

The view of Adewumi (1986) is that fraud is a conscious premeditated action of a person or group of persons with the intention of altering the truth and or fact for selfish personal monetary gain. It involves the use of deceit and trick and sometimes highly intelligent cunning and know-how. Black (1979) defines fraud as all multifarious means which human ingenuity can devise, and which are resorted to by one individual to get an advantage over another by false suggestions or suppression of the truth. It includes all surprises, tricks, cunning or dissembling, and any unfair way which another is cheated. Under common law, three elements are required to prove fraud; a material false statement made with intent to deceive a victim's reliance on the statement and damages.

Sutherland (1943) and ACFE (2010) define occupational fraud as the process of using one's occupation or responsibility to satisfy his personal interest by enriching himself through the deliberate abuse of power. According to Merriam Webster's Dictionary of Law (1996) as quoted in Manurung \& Hadian (2013), fraud can be defined as: any act, expression, omission, or concealment calculated to deceive another to his or her disadvantage, specifically, a misrepresentation or concealment with reference to some fact material to a transaction that is made with knowledge of its falsity. And or in reckless disregard of its truth or falsity and worth the intent to deceive another and that is reasonably relied on by the other who is injured thereby.

Ernst \& Young (2009) defines fraud as an act of deliberate action made by an entity, knowing that such action can result in a possession of unlawful benefits. Adeniyi (2004) and Institute of Chartered Accountants of Nigeria (ICAN) (2006), state that fraud is an intentional act of individuals among management, employees or third parties who produce errors in financial reporting in favour of their personal desires.

The Criminal Code Section 380 Sub-Section One stated that everyone who, by deceit, falsehood or other fraudulent means, whether or not it is a false pretence with the meaning of this Act, defrauds the public or any person, whether ascertained or not, of any property, money or valuable security or any service. This means that fraud is criminal deception intended to financially benefit the deceiver. The below table shows some fraud schemes and why it occurs.

Table 1: Construction Phase Fraud Schemes

\begin{tabular}{|l|l|}
\hline \multicolumn{1}{|c|}{ Type of Scheme } & \multicolumn{1}{c|}{ Why Does it Occur? } \\
\hline$>\begin{array}{l}\text { Inflate invoices for hiring of } \\
\text { equipment and labour. }\end{array}$ & $\begin{array}{l}\text { Over dependence on manual processes that are not strictly enforced at } \\
\text { the site. This encourages manipulation of equipment and resource usage. }\end{array}$ \\
\hline $\begin{array}{l}\text { Pilferage of inventory and } \\
\text { scrap. }\end{array}$ & $\begin{array}{l}\text { Lack of robust controls to check the high movement of material and } \\
\text { vehicles. }\end{array}$ \\
\hline $\begin{array}{l}\text { Inflated work certification for } \\
\text { earth work done. }\end{array}$ & $\begin{array}{l}\text { Dependence on contractors to complete such work and lack of resources } \\
\text { to monitor and validate the work completed. Also, post completion } \\
\text { checks are not possible in such cases. }\end{array}$ \\
\hline$>\begin{array}{l}\text { Collusion between vendors and } \\
\text { employees to inflate quotations. }\end{array}$ & $\begin{array}{l}\text { Prevalence of high quantity of level procurement (including emergency } \\
\text { procurement) at project sites. Retrospective approvals are common, } \\
\text { thereby providing the opportunity to inflate the cost incurred. }\end{array}$ \\
\hline$>\begin{array}{l}\text { Issuance of multiple change } \\
\text { orders leading to inflation of } \\
\text { contract value. }\end{array}$ & $\begin{array}{l}\text { Frequent changes made to be contracted scope of work, make it difficult } \\
\text { to monitor whether changes were really and if proper approvals were } \\
\text { sought }\end{array}$ \\
\hline
\end{tabular}

Source: Deloitte Teething issues: Managing fraud and dispute challenges in the infrastructure sector (2014). 
Table 2: Operational Phase Fraud Schemes

\begin{tabular}{|c|c|}
\hline Type of Scheme & Why Does it Occur? \\
\hline $\begin{array}{l}\text { Revenue leakage at toll } \\
\text { plazas. }\end{array}$ & $\begin{array}{l}\text { Manipulation of IT systems or collusion between staff to record less than the } \\
\text { actual price of the toll ticket, and siphoning off the balance. Absence of real } \\
\text { time reporting } \\
\text { / monitoring of IT systems. }\end{array}$ \\
\hline $\begin{array}{l}\text { Under-reporting of revenue } \\
\text { by lessees at airport/ malls } \\
\text { or leakage at duty free } \\
\text { outlets. }\end{array}$ & $\begin{array}{l}\text { Hybrid revenue structure that seeks part of revenue earned by lessee in } \\
\text { addition to a fixed lease rental. Lessee therefore declares less revenues and } \\
\text { pays the operator much less than the actual amount, while pocketing it for } \\
\text { himself. Lack of spot audits or system integration at the point of sale adds to } \\
\text { this. }\end{array}$ \\
\hline $\begin{array}{l}\text { Leakage in container } \\
\text { demurrage charges, } \\
\text { franking revenue and stamp } \\
\text { duty revenue at ports. }\end{array}$ & $\begin{array}{l}\text { Manipulation of records pertaining to use of cont } \\
\text { staff at lessor company with the lessee company } \\
\text { Manipulation of records pertaining to use of cont } \\
\text { staff at lessor company with the lessee company }\end{array}$ \\
\hline $\begin{array}{l}\text { Leakages in metering and } \\
\text { billing at power distribution } \\
\text { companies. }\end{array}$ & $\begin{array}{l}\text { Collusion between employees and consumers to record lower power } \\
\text { consumption in exchange for bribes or simply allowing the employee to } \\
\text { pocket the differential amount. }\end{array}$ \\
\hline $\begin{array}{l}\text { Theft of cash at courier } \\
\text { company. }\end{array}$ & $\begin{array}{l}\text { Collusion amongst staff whereby amount on receipts is recorded lower than } \\
\text { actual and the balance cash is pocketed. Overdependence on mutual receipts } \\
\text { makes the audit process tedious. }\end{array}$ \\
\hline
\end{tabular}

Source: Deloitte Teething issues: Managing fraud and dispute challenges in the infrastructure sector (2014).

\section{The Concept of Infrastructure Development}

According to Sullivan \& Sheffrin (2003), infrastructure could be defined as organizational structure and physical amenities that are needed by the community in general. These infrastructures include industries, buildings, roads, bridges, health services and many others. Also, added that, infrastructure development is needed economically and it affects the demand and supply as well buying and selling activities. Alleman et al. (1994) and Ghafoor (2000), for instance, viewed infrastructural investment as an investment that can contribute to the increase of economic growth. Infrastructure development is none other than a mechanism that increases the living quality of a society. In terms of economy, infrastructure development can impact the employment rate, productivity and income as well as give an added value.

The concept of infrastructure development also refers to the provision of fundamental infrastructure facilities such as the construction of roads and highways, availability of transportation, bridges, and ports and telecommunication systems (Cronin, McGovern, Miller \& Parker, 1995; Madden \& Savage, 1998). The definition of infrastructural services, as given by Jacobson \& Tarr (1995), was that it is the structures and networks that frame and hold cities, making it possible to carry out economic and social activities like power and water supply, telecommunications, as well as others.

African Development Bank (1999) and Oshikoya, Jerome, Hussian, and Mlambo (1999), stating that developing infrastructure can help decrease poverty in two significant ways: first is the link that resides between infrastructural development and economy development, and second is the link between infrastructural development and the pro-poor growth process. In both cases, the outcome is poverty reduction. The preparation of basic infrastructure such as markets, schools and good roads can help to reduce unemployment and illiteracy, which will lead to higher income and better nutrition. Most infrastructure are now crumbled and need fixing or reformation. According to Kathmandu Final Workshop Report (2009), infrastructure can help solve four problems: social; health and environment; development; and economic.

According to World Bank (2002) $50 \%$ of the city dwellers in Nigeria lack access to potable water and sanitation. About forty-four (44) percent of households have their own private boreholes and many rely on water vendors whose high prices amount to more than 30 percent of the household income for the poorest, as a result large proportion of households have resorted to drawing water from unhygienic sources (Alabi \& Ocholi, 2010). AICD (2011) reported that only $13 \%$ of the population has access to improved latrines and one in three Nigerians continues to practice open defecation. This practice continues to increase with little effort toward improving total sanitation. AICD (2011) reported that in 1998, 24 percent of the population practiced open defecation; within 10 years this had increased to 29 percent Nigeria is said to be generating 80,000 metric tonnes of solid waste daily, but only $30 \%$ of this is collected for proper disposal.

The Nigerian Housing deficit is estimated at over 14 million units. The housing reform efforts by previous and present administrations have the objective of providing the much needed dwelling units. These inadequacies and lack of infrastructure may be attributed to problems such as lack of private sector participation, negligence of the duty of maintenance officers, misguided policies and corruption among others (Obiegbu, 2005; Alabi \& Ocholi, 
2010; Ndiyo \& Ogar, 2012; Vetiva Research, 2011; Swarup, 2013).

African Infrastructure Country Diagnostic AICD (2011) reported some of the achievements and challenges in Nigeria infrastructural sectors, in which was stated that Nigeria has developed an extensive national road network (paved and unpaved road network) more than some African countries but the problems of road network maintenance are obviously much more severe at all levels in the nation. Although Nigeria established Federal maintenance agency (FERMA) to serve as a stopgap undertaking more substantial reforms, but still rely on traditional budget allocations to fund road maintenance and rehabilitation. Considering the current state of road maintenance in Nigeria it will be better if adequate funds are for road maintenance were being secured through the budgetary process. Nigerian has one of the most extensive National rail networks in Africa, second only to South Africa in length and historically Nigeria's railway was among the best in West Africa. Despite Nigeria's potentially significant demand for rail, traffic volumes have collapsed due to deficient performance and erratic service. Nigeria's port system has traditionally put a brake on economic development, due to poor performance and high costs. As of 2006, the performance parameters for Nigeria's major ports were very poor by global and even African standards. Despite the important progress made by Nigeria's port sector reforms, they are still facing a lot of challenges for example, there is need to improve both marine and landsides access to port as well as plan a new capacity infrastructure and there is need to managed some of the broader based problems that negatively impact the port system such as poor customs performance and corruption. Nigerian's are still doing better in terms of sanitations, at least average Nigerians can have access to flush toilets and more than one-third of Nigerians rely on improved latrines but still yet some Nigerians continues to practice open defecations. Despite high levels of electrification, Nigeria's power has struggled to provide an adequate power supply. The economic impacts of Nigeria's power deficit are substantial.

Table 3: Achievements and Challenges in Nigeria's Infrastructure Sectors

\begin{tabular}{|c|c|c|}
\hline & Achievements & Challenges \\
\hline $\begin{array}{ll} & \text { Air } \\
\text { transport }\end{array}$ & $\begin{array}{l}\text { 1. Recent expansion of domestic market. } \\
\text { 2. Emergence of important regional } \\
\text { carriers. } \\
\text { 3. New routes to Europe and the United. } \\
\text { 4. States Significant improvements in } \\
\text { safety Oversight. }\end{array}$ & $\begin{array}{l}\text { 1. Developing potential as regional air } \\
\text { transport hub. } \\
\text { 2. Concession of airport terminals. }\end{array}$ \\
\hline - $\mathrm{ICT}$ & $\begin{array}{l}\text { 1. Extensive low-cost GSM coverage } \\
\text { 2. Vibrant competitive fixed-line sector } \\
\text { 3. Extensive private fiber-optic backbones }\end{array}$ & $\begin{array}{l}\text { 1. Increasing penetration of ICT services } \\
\text { 2. Reducing cost of Internet services } \\
\text { 3. Addressing market-efficiency gap }\end{array}$ \\
\hline - $\quad$ Power & $\begin{array}{l}\text { 1. High rates of electrification. } \\
\text { 2. Sector restructuring and tariff hikes in } \\
\text { progress. }\end{array}$ & $\begin{array}{l}\text { 1. Investing to improve service reliability. } \\
\text { 2. Addressing huge sector inefficiencies. }\end{array}$ \\
\hline - $\quad$ Railways & Extensive national rail network. & Improving performance to recapture traffic. \\
\hline - $\quad$ Roads & Extensive national road network. & $\begin{array}{l}\text { 1. Increasing funding for road maintenance. } \\
\text { 2. Improving rural access. }\end{array}$ \\
\hline $\begin{array}{ll}- & \text { Water } \\
& \text { resources }\end{array}$ & Progress on institutional framework & $\begin{array}{l}\text { Developing huge high-return irrigation } \\
\text { potential. }\end{array}$ \\
\hline - $\quad$ Ports & $\begin{array}{l}\text { 1. Adoption of modern landlord model. } \\
\text { 2. Award of numerous concessions. }\end{array}$ & $\begin{array}{l}\text { 1.Improving customs performance } \\
\text { 2.Improving land and marine access } \\
\text { 3. Planning for new capacity additions }\end{array}$ \\
\hline $\begin{array}{l}\text { Water } \\
\text { and } \\
\text { sanitation }\end{array}$ & & $\begin{array}{l}\text { 1. Improving access to improved water } \\
\text { services. } \\
\text { 2. Reversing growth in open defecation. } \\
\text { 3. Addressing utilities' huge inefficiencies. } \\
\text { 4. Paying greater policy attention to wells } \\
\text { and boreholes. } \\
\text { 5. Improving quality of traditional latrines }\end{array}$ \\
\hline
\end{tabular}

Source: Authors' elaboration of AICD findings.

Note: $\mathrm{ICT}=$ Information and Communications Technology; GSM = Global System for Mobile Communications.

\section{Fraud in Infrastructural Sector in Nigeria.}

There are a lot of challenges facing the development of infrastructure in Nigeria for example petroleum revenues is one of the fraudulent sector in Nigeria because they constitute over $75 \%$ of total government receipts and well over $90 \%$ of export earnings (Oil and Gas Industry Audit Report, 2014). Since the country's independence, fraud has been perpetuated by macroeconomic mismanagement by successive governments, both military and civilian 
regime. For decades, political and business elites have benefited from several well-practiced forms of economic fraudulent, despite its negative impact on infrastructure. The Nigerian government continues to operate a range of different petroleum related subsidies, all of which have, to some extent, been converted into mechanisms for siphoning public funds. The best known subsidy scandal was the \$6-billion fuel importation fraud scheme that flustered the Jonathan government in 2012 (Nigeria Fuel Subsidy Report, 2012).

Nigeria's industrial and manufacturing sector has declined steadily since the 1970s, hamstrung by infrastructure shortfalls, foreign exchange and credit shortages, misguided fiscal and trade policies. Both federal and state governments have nevertheless cohered on to loss making state owned enterprises, often because they are important mechanisms for distributing patronage and siphoning public funds. Nigeria is littered with these so called 'white elephant' projects: monuments to industrial corruption that consume large quantities of public funds every year despite incurring huge losses (Robinson \& Torvik, 2005).

Since 1979, the federal government has invested well in excess of $\$ 5$ billion in the moribund facility, which has never produced any steel (Yekeen, 2018). The government has also paid out over $\$ 30$ billion ( $\$ 83.3$ million in 2018 dollars) as workers' salaries since 2010 and needs to make an additional $\$ 1.2$ billion investment to make the facility operational, according to officials (Umoru, 2018). Yet despite its continued drain on public resources, Ajaokuta remains a political football as federal and state lawmakers tussle over ongoing efforts to concession the plant to private investors (Akinrefon, Ovuakporie \& Nwabughiogu, 2018).

The impact of agricultural fraud is disproportionately great because the sector is the backbone of Nigeria's non-oil economy, accounting for roughly $30 \%$ of GDP. It also has an outsized impact on the country's poorest citizens. The sector employs more people than any other but is dominated by small-scale subsistence farming. Nigeria's land tenure laws, which allows corruption-prone state and local officials' power to grant and revoke occupancy rights, discourage farmers from investing in their smallholdings. These laws also make establishing mechanized, well-irrigated, industrial-scale farms inordinately difficult. Smallholders are also hurt when government officials misappropriate agricultural subsidies by granting them to family and friends or to shell companies owned by political elites (Godson-Ibeji, Anyoha, Chikaire \& Ani, 2016). Between 1980 and 2010 , agricultural subsidies totaled $\$ 873$ billion ( $\$ 5.8$ billion); of that amount, an estimated $\$ 776$ billion ( $\$ 5.2$ billion) was lost to corruption (Udo, 2013).

Even as the federal and state governments have spent billions on roads, railways, ports, electrical power, schools, hospitals, universities and other economic enablers, they have realized few gains. By inflating contracts, soliciting kickbacks, and mismanaging budgets, venal officials have derailed countless such projects. Spending on transportation infrastructure roads, rail and airports are fraud prone. Beyond its drain on public funds, corruption in the construction industry has outsized economic and even human costs. Nigeria's economic growth has long been constrained by its inadequate transportation infrastructure. Furthermore, catastrophic building collapses kill scores of Nigerians each year because contractors use substandard materials and bribe building inspectors to ignore their shoddy works and/or lack of permits. Such corrupt corner-cutting caused two deadly church collapses, which killed 110 people in Lagos in 2014 and 160 people in Akwa Ibom State in 2016 (Associated Press, New York Times, December 11, 2016). 2

A study in 2015 estimated that Nigeria has lost $\$ 11$ trillion (\$64.7 billion) to corruption in the power sector between 1999 to 2017 (Socio-Economic Rights and Accountability Project (SERAP), August 2017). The more money the government invests in the power sector, the less power the country has: Nigeria (with a population near 200 million) currently generates roughly the same amount of power (4,500 megawatts) as Oman (with a population of about 4.5 million) (Asu, 2018). In an attempt to revitalize the sector and root out corruption, the 2013 unbundling and privatization of Nigeria's power generation and distribution networks was poorly executed and did little to remedy mismanagement, graft, and chronic underperformance. Most of the winning bidders had no prior experience in the power sector and little or no capacity to succeed (SERAP, 2017).

Even though Nigerians near-universally recognize education as key to socioeconomic advancement, the country's education sector has been hurt by decades of corruption and mismanagement. Whether it be officials embezzling money meant to build, furnish and equip schools or extorting money from students in return for admission or exam grades, educational corruption remains a nationwide problem. Nigerian universities have been especially hard hit by the effects of corruption, which has hollowed out once-proud institutions like the University of Ibadan and the University of Nigeria at Nsukka (Federal Government Audit Exposes Multi-Billion Naira Fraud in University of Ibadan, Sahara Reporters, July 3, 2017). Several government entities involved in education like the Joint Admissions and Matriculation Board (JAMB), the Tertiary Education Trust Fund (TETFUND) and the Universal Basic Education Commission (UBEC), to mention a few have experienced fraud scandals in recent years. One of such incident recently went viral after a JAMB official, accused of embezzling $\$ 36$ million $(\$ 100,000)$, claimed that a snake had slithered into her office and had eaten the money ("Nigerian Snake Ate Millions of Naira, Clerk Says," BBC News, February 12, 2018).

Nigeria's public health infrastructure is poor and incapacitated by a lot of mismanagement, corruption and funding shortfalls. Nigeria spends a paltry $\$ 217$ per capital on healthcare annually; taking into account corruption, 
real expenditures are likely far lower (World Health Organization, 2018). Health-related corruption recently made headlines after Nigeria's health minister sacked the head of the National Health Insurance Scheme (NHIS) after an internal investigation found he misused $\$ 19$ million (\$2.5 million) in training funds and steered consulting work to his brother's firm, among other malpractices (Owoseye, 2018). Buhari controversially overruled his minister and unilaterally reinstated the NHIS head, who is still under EFCC investigation (NHIS Boss' Reinstatement Doesn't Stop EFCC Investigation - FG,” Channels TV, February 7, 2018).

The Impact of Fraudulent Practices on Infrastructural Development in Nigeria.

Nigeria is often referred to as the "Giant of Africa", owing to its large population and economy (Peter, 1987). Nigeria is the most populous country in Africa with more than 200 million people. It is a nation made of more than 250 ethnic groups, 380 languages, and a various range of cultural and religious beliefs and practices and yet infrastructural development in Nigeria are very challenging due to fraudulent practices.

In health care sector, fraud is likely to damage the ability of the health care system to deliver adequate health care to the people who supposed to benefit most and high level of fraudulent in health sector will increase inequality and cause health status to devolve especially among the poor people. The first WHO Global Status Report on non-communicable disease listed Nigeria and other developing countries as the worst hit with deaths from non-communicable diseases (Bolaji, 2016). According to the 2011 World Health Statistics, malaria mortality rate for Nigeria is 146 per 100,000 population (WHO, 2011). Nigeria has one of the highest Tuberculosis burden in the world (311 per 100,000) resulting in the largest burden in Africa. (WHO, 2009). The inability of the government to efficaciously deal with the fraudulent in public health sector in the nation has contributed to the high level of poverty and the weakness of the health system. Households and individuals in Nigeria bear the encumbrance of a dysfunctional and unjust health system. Because of the inadequate health sector, it has led to a consistent mass migration of medical practitioners out of the country and this is in relation with poor working conditions in healthcare centers and it also led to shortage of staff across all the levels of healthcare centers in the nation.

The maternal mortality ratio for Nigeria remain high at 814 per 100,000 live are lost after births according to 2016 World Health Statistics (UNICEF \& WHO, 2016). In some states in Nigeria, pregnant women and children under five years are generally charged fees to access health care services, despite the federal government's declaration of free health for pregnant women and children under five years in 2005 (Ijadunola, 2013). The quality of health care services delivered is bad and it remains a major concern, because most of the public health centers facilities that are supposed to meet the health needs of the people are in a poor state due to fraudulent in health sector (Abdulraheem, Olapipo \& Amodu, 2012).

Malaria remains the foremost killer disease in Nigeria (FMOH \& PSI, 2002). It has the highest burden of disease in Nigeria with an estimated 300,000 children dying of malaria each year. It accounts for over $25 \%$ of infant mortality (children under age one), $30 \%$ of child-hood mortality (children under five) and $11 \%$ of maternal mortality. At least $50 \%$ of the population has at least one episode of malaria annually, while children aged less than 5 years have 2 to 4 attacks annually (NDH, 2009). However, the effective public health intervention that supposed to have prevent most deaths exist, but there is no proper supervision by the government of the nation. The crude death rate, life expectancy, infant mortality rate, human development index, maternal mortality rate, the proportion of Gross National Product (GNP) spent on health services are testaments to this fact that the above indicators do not show that Nigeria is a country that supports the survival of the Nigerian people in a world where their fellow human beings live long enough due to increased life expectancy and proper investment in the health of the people (Bolaji, 2016).

A nation with a predominately unhealthy population cannot advance economically, increase her GDP nor experience economic development which is evaluated primarily by economic growth. Poor health facilities as caused young Nigerians to die of different preventable diseases such as hypertension, cancer, obesity, HIV/AIDS, tuberculosis, malaria, vaccine preventable disease of childhood, diarrheal, acute respiratory infections, maternal and neonatal conditions due to inadequate investment in preventive services. The cost of illness both direct and indirect has continued to mendicant most of the citizens and this affect economic growth as well as development. Once the governments begin to tackle fraud in health sector, the better the growth of the economic.

A major and integral part of sustainable development is provision of sound infrastructure such as road and transportation, water supply and sanitations, power and telecommunications but all these infrastructures are major problems facing Nigeria today due to the act of fraud in most of the sectors. Most of the recently constructed road infrastructures are badly built with low quality materials and this is as a results of fraudulent in construction sectors. Good road transport has so many benefits to countries, companies and individuals. It can facilitate the movement of goods and people, create employment, support economic growth, enhance access to education and health care services, as well as connect people to families and entertainment and improvement in road infrastructure will positively impacts the GDP of the nation's. Travelling is very difficult and sometimes almost impossible especially during the raining season due to lots of uneven surfaces, potholes, and eroded areas. Bad road lead to loss of 
revenue and it gives chance for armed robbers, rapists and other miscreants to hide themselves in bad portions of the road which always cause loss of life. Some of the roads are covered by water during the raining season because of lack of proper drainage. The poor state of Nigeria road networks has turned to dead zones due to the number of accidents that are recorded daily on these roads. Poor drainage can lead to flooding, resulting in property loss, and people may even be forced to move to escape floodwaters. Flooding may also damage water supply infrastructure and contaminate domestic water sources. In some places where drainage and sanitation are poor, water always runs over the ground during rainstorms, pick up dejection and contaminates water resources. This impact negatively to the spread of the diseases and also flooding itself may displace populations and lead to further health problems. Furthermore, most cities in Nigeria including Ibadan, the capital of Oyo State are facing issues like poor drainage systems Offiong et al. (2009) and water tight structures which result to flooding (Belete, 2011).

Fraudulent practices in the water and sanitation sector also has devastating short-term impacts, endangering health outcomes, food security and people's livelihoods, which in turn undermine economic development, environmental sustainability and socio-political stability. Fraud can pervade all aspects of water management, inflating the costs of drinking water, hampering reliable supply of irrigation or fuelling large scale water pollution in many countries of the world, all of which endanger citizens and complicate efforts to mitigate and adapt to climate change (Transparency International, 2008). The act of fraudulent in water and sanitations sector impacts negatively on the health of those living in poverty by sabotage their food security and spread of water-borne diseases (Duflo, Galiani \& Mobarak, 2012).

\section{Policy Recommendations}

In order to curb fraudulent in infrastructural development, the following recommendations are essential:

1. Governments should transform all infrastructure sectors to meet the needs of the people and there is also need for regulatory authorities in order to regulate the reliability and output of infrastructure provide.

2. Independent Corrupt Practices and other Related Offences Commission (ICPC) and the Economic and Financial Crimes Commission in Nigeria (EFCC) should collaborate with local agencies to investigate all financial crimes in all infrastructure sectors in order to reduce the rate of fraud in all sectors.

3. Government need to contrive health care reforms in order to deal with lack of social and financial protection for the poor and vulnerable people. The federal government need to mandate all states to provide health insurance coverage to all the residents of the state.

4. There must be relevant supervisory agencies in order to ensure good administrative abidance with specified rules and regulations in coaction with all anti-corruption organizations.

5. All public office occupants should always be monitored with a great sense of accountability through adequate checks and balances and government should encourage a culture of transparency through the publication of all expenditures and also the presence of whistle-blowing mechanisms will be an advantage if implemented in order to reduce fraud in all infrastructural sectors.

\section{References}

Abdulraheem, I.S., Olapipo, A.R, \& Amodu, M.O (2012). Primary health care services in Nigeria: Critical issues and strategies for enhancing the use by the rural communities. Journal of Public Health and Epidemiology, 4:5-13.

Adeniyi (2004). Auditing and Investigation, Lagos: EL-Toda Ventures Limited Black Dictionary (1997). $5^{\text {th }}$ Edition.

African Development Bank (1999). Infrastructure development in Africa. African Development Report 1999, New York: Oxford University Press.

African Infrastructure Country Diagnostic AICD (2011), Nigeria's Infrastructure: A Continental Perspective, Publication of the International Bank for Reconstruction and Development, the World Bank, Washington DC.

Alabi, M.O. \& Ocholi, I. (2010), State of Infrastructure and Funding in Kogi State, Nigeria. Current Research Journal of Social Sciences, Vol. 2 No. 3, pp. 209-213.

Alexandra G., Aaron S., \& Christina K. (2015). Inside NNPC Oil Sales: A Case for Reform in Nigeria, Natural Resource Governance Institute.

Alleman, J., Hunt, C., Michaels, D., Mueller, M., Rappoport, P., \& Taylor, L. (1994). Telecommunications and economic development: Empirical evidence from Southern Africa. Paper presented at the 10th Biennial International Telecommunications Society Meeting, Sydney.

Akinwale, A. (2010). The menace of inadequate infrastructure in Nigeria. African Journal of Science, Technology, Innovation and Development, Vol. 2, No.3. Pp.207-225.

Association of Certified Fraud Examiners (2010). Report to the Nation on Occupational Fraud. Retrieved May 26, 2014

Bassey Udo (November 22 $\left.2^{\text {nd }}, 2013\right)$. Nigeria Saves N776 Billion from Fertilizer Fraudsters in One Year Minister. The Premium Times, Retrieved from https://www.premiumtimesng.com/news/150135-nigeria- 
saves-n776-billion-fertiliser-fraudsters-one-year-minister.html.

Black, H.C. (1979), Black's law Dictionary, 5th edition, St. Paul Minnesota, West Publishing Co.

Bolaji SA, (2016). Addressing the Public Health Challenges Nigeria Faces. Retrieved from https://www.inigerian.com/addressing-the-public-healh-challenges-nigeria-faces. (Accessed: March $22^{\text {nd, }}$ 2020).

Godson-Ibeji, C.C., Anyoha, N.O., Chikaire, J.U., \& Ani, A.O. (2016). Corruption and Sharp Practices: Impediments to Agriculture and Rural Development in Nigeria, Journal of Agricultural Economics, Extension and Rural Development 4, no. 8: 565.

Centre for Disease Control and Prevention (CDC), Nigeria report 2013.

Cronin, F. J., McGovern, P. M., Miller, M. R., \& Parker, E. B. (1995). The Rural Economic Development Implications of Telecommunications Policy, 19(7), 545-559.

Dapo Akinrefon, Emman Ovuakporie, \& Levinus Nwabughiogu (March $\left.2^{\text {nd }}, 2018\right)$. Ajaokuta: Witnesses Throw Up Can of Worms at Reps Sectoral Hearing. The Vanguard, Retrieved from https://www.icirnigeria.org/investigation-the-real-reasons-itakpe-and-ajaokuta-steel-companies-are-lyingfallow/

Duflo, E., Galiani, S. \& Mobarak, M. (2012). Improving Access to Urban Services for the Poor.

Edelherz (1977). White-collar and Professional Crime: The Challenge for the 1980s. American Behavioural Scientist, Vol. 27, Pp $109-128$.

Ernst, \& Young, (2009). Detecting Financial Statement Fraud. Retrieved: 19 March 2020 from http://www.ey.com/Publication/vwLUAssets/FIDSFI

Federal Ministry of Health Nigeria (FMOH) and Population Services International (PSI) 2002.

Femi Asu (March, 2018). Flood: Shiroro Power Plant Shuts Down. The Punch, Retrieved from http://punchng.com/flood-shiroro-power-plant-shuts-down/.

Gire, J. T. (1999). A Psychological Analysis of Corruption in Nigeria. Journal of Sustainable Development. Retrieved 24 March 2020 from http://www.jsdafrica.com/Jsda/Summer1 999/articlespdf/ARC\%20.

Henry Umoru (January 31, 2018). Why We Can't Concession Ajaokuta Steel Plant-FG. The Vanguard, Retrieved from https:/www.vanguardngr.com/2018/03/ajaokuta-witnesses-throw-can-worms-reps-sectoral-hearing/.

Hoffman, L.k., \& Patel R.N. (2017). Collective Action on Corruption in Nigeria: A Social Norms Approach to Connecting Society and Institutions. The Royal Institute of International Affairs, 2017, ISBN 978178413 2170

Institute of Chartered Accountants of Nigeria (2006). Accounting, Auditing \& Accountability, Journal 5(1), 39 62. Financial Reporting and Audit Practice, Lagos: VI Publishing Ltd.

James A. Robinson \& Ragnar Torvik (2005). "White Elephants," Journal of Public Economics 89: 197-210.

Independent Corrupt Practices and other Related Offences Commission (2006). Nigeria and Corruption. Independent Corrupt Practices and Other Related Offences Commission.

Ijadunola KT (2013). Free health services in Nigeria: how beneficial to the poor. Accessible: http://www.oauife.edu.ng/wp-content/uploads/2013/05/Dr.-K.-T.-Ijadunola-...

Jacobson, C. A., \& Tarr, J. A. (1995). Ownership and financing of infrastructure: Historical Perspective, World Bank Policy Research Working Paper No. 1281.

Kathmandu Final Workshop Report (2009). Governance and Infrastructure Development Challenges in the Kathmandu Valley.

Manurung D. T. H., \& Hadian, N. (2013). Detection Fraud of Financial Statement with Fraud Triangle. Proceedings of the 23rd International Business Research Conference, pp. 18-20

Marriott Hotel, Melbourne, Australia, ISBN: 978-1-922069-36-8.

Mymensigh and Ogere (2018). How the Growth of Cities Changes Farming. Economist.

Nigeria Demographic and Health Survey (NDHS). Demographic and Health Survey Report-2008, Nigeria: NDHS 2009.

Nigeria World Health Organization (2018). http://www.who.int/countries/nga/en/.

Offiong, R. A., Atu, J. E., Njar, G. N., \& Iwara, A. I. (2009). Effects of Land Use Change on Soil Physico-Chemical Properties in a South-Southern Nigeria. African Journal of Environment, Pollution and Health, 7(2), 47-51.

Oil and Gas Industry Audit Report (2014). Nigeria Extractive Industries Transparency Initiative. Available at: https://eiti.org/sites/default/files/documents/neiti-oil-gas-report-2014-full-report301216.pdf. (Accessed: March 28 ${ }^{\text {th }}$, 2020).

Oshikoya, T.W., Jerome, A., Hussian, M.N., \& Mlambo, k. (1999). Closing the Infrastructure Deficit. In proceedings of the African Development Bank Conference on"Can Africa Claim the $21^{\text {st }}$ Century?" 6-9 July Abidjan.

Sullivan, A. and Sheffrin, M. S. (2003). Economics: Principles in action. Upper Saddle River, New Jersey 07458: Pearson Prentice Hall.

Sunday, O.O. \& Okon, E.B. (2013). Infrastructure Investment Institutional Quality and Economic Growth in 
Nigeria; an interactive approach. European journal of Humanities and Social Sciences. Vol.26, No.1, pp.1342- 1358.

SERAP (2017). From Darkness to Darkness: How Nigerians Are Paying the Price for Corruption In the Electricity Sector. Available at: http://serap-nigeria.org/wpcontent/uploads/2017/08/CORRUPTION-IN-ELECTRICITY-REPORT-A4.pdf. (Accessed: March 31 ${ }^{\text {st }}$, 2020)

Terhemba Dakaa, (2017). Nigeria: N726 Billion East-West Road Project Designed to Fail GOCCT, All Africa. Available at http://allafrica.com/stories/201712140150.html. (Accessed: March $24^{\text {th }}, 2020$ )

Transparency International Indonesia, (2008). Global Corruption Report 2008: Being Cautious About Corruption in the Water Sector.

Uhunmwuangho, S.O \& Christopher, E. (2012). Analysis of Socio-political Implication of Infrastructural Decay in Nigeria. African Research Review. Vol.6, No.4, pp.40-58. DOI: http://dx-doi.org/10.4314/afforev.v6144.

UNICEF and WHO (2015). Countdown to 2015: A Decade of Tracking Progress for Maternal,

Newborn and Child Survival (The 2015 Report).

Usman, S. (2013). National Integrated Infrastructure Master Plan. An Imperative for a Sustainable Economic Growth and Development. Abuja, National Planning Commission.

Yekeen Akinwale (2018). Investigation: The Real Reasons Itakpe and Ajaokuta Steel Companies Are Lying Fallow, International Centre for Investigative Reporting (Nigeria), Retrieved From https://www.icirnigeria.org/investigation-the-real-reasons-itakpe-and-ajaokuta-steel-companies-are-lyingfallow/

World Bank (2002), An Assessment of the Private Sector in Nigeria, The Bank Group, Sept. Washington D.C, available at: http://www.journals.cambridge.org/production/action/cjoGetfulltext (Accessed: March 29 , 2020).

World Health Organization. Global Tuberculosis Report-2009. Geneva: WHO 2009.

World Health Organization. World Health Statistics Report-2011. Geneva: WHO 2011. 